\title{
SISTEM PENDUKUNG KEPUTUSAN PENENTUAN SISWA AKSELERASI MENGGUNAKAN FUZZY MULTI ATTRIBUT DECISION MAKING (FMADM) DAN SIMPLE ADDITIVE WEIGHTING (SAW)
}

\author{
Prasiska Dwi Purwanti, Joseph Dedy Irawan, Febriana Santi Wahyuni \\ Program Studi Teknik Informatika S1, Fakultas Teknologi Industri \\ Institut Teknologi Nasional Malang, Jalan Raya Karanglo km 2 Malang, Indonesia \\ 1618067@scholar.itn.ac.id
}

\begin{abstract}
ABSTRAK
Penyelenggaraan pendidikan di Indonesia yang berorientasi kepada kuantitas untuk pontensi belajar siswa. Potensi belajar siswa ada yang lambat, sedang dan cepat (mempunyai kemampuan/kecerdasan istemewa) dan siswa yang mempunyai kemampuan perlu mendapatkan pelayanan khusus sesuai dengan kecepatan belajarnya. Di dunia pendidikan di adakan beberapa program termasuk salah satunya program akselerasi yang saat ini sudah di laksanakan oleh beberapa sekolah. Program akselerasi di desain dalam bentuk pemadatan waktu menjadi dua tahun dari tiga tahun di masa normal sekolah menengah atas (SMA). Penentuan siswa ini sendiri di perlukan sebuah Sistem Pendukung Keputusan untuk penentuan siswa yang lolos dalam seleksi tes untuk akselerasi agar maksimal. Sistem ini untuk membantu dalam pengambilan keputusan yang lebih tepat dalam pemilihan siswa lolos akselerasi. dengan penentuan akselerasi siswa menggunakan metode Fuzzy Multi Attribute Decision Making (FMADM) untuk menentukan bobot kriteria dan Simple Additive Weighting (SAW) untuk perangkingan, sehingga dapat membantu guru untuk menentukan siswa yang lolos dalam akselerasi. Dengan adanya Sistem Pendukung Keputusan ini dapat mempermudah dalam menentukan siswa yang lolos ke kelas akselerasi..

Perhitungan penentuan siswa akselerasi dengan metode SAW dan FMADM pada sistem sudah sesuai dengan yang digunakan manual pada excel. Hasil uji keputusan pengguna melibatkan guru
\end{abstract}

Kata kunci : Sistem pendukung keputudan, Simple Additive Weighting, penentuan siswa akselerasi ,Fuzzy Multi Attribute Decision Making

\section{PENDAHULUAN \\ 1.1 Latar Belakang}

Penyelenggaraan pendidikan di Indonesia yang berorientasi kepada kuantitas untuk pontensi belajar siswa. Potensi belajar siswa ada yang lambat, sedang dan cepat (mempunyai kemampuan/kecerdasan istemewa) dan siswa yang mempunyai kemampuan perlu mendapatkan pelayanan khusus sesuai dengan kecepatan belajarnya. Di dunia pendidikan di adakan beberapa program termasuk salah satunya program akselerasi yang saat ini sudah di laksanakan oleh beberapa sekolah. Siswa yang mempunyai kemampuan di atas rata-rata mempunyai kebutuhan yang berbeda. Bagi siswa dalam kategori ini perlu adanya pelayanan pendidikan khusus. Salah satu alternatif yang bisa dilakukan oleh sekolah adalah dengan menyelenggarakan akselerasi(Program percepatan belajar). Program akselerasi di desain dalam bentuk pemadatan waktu menjadi dua tahun dari tiga tahun di masa normal sekolah menengah atas (SMA).

Untuk memecahkan masalah ini dilakukan sebuah penelitian untuk membangun sebuah Sistem Pendukung Keputusan untuk penentuan siswa akselerasi dengan perbandingan alternatif dan kriteria yang telah ditentukan. Sistem ini akan membantu para pembuat keputusan bisa di lakukan dengan lebih cepat dan akurat.
Dari metode yang digunakan yaitu metode Simple Additive Weighting $(S A W)$ dan metode Fuzzy Multi Attribute Decision Making. Konsep dasar dari metode SAW penjumlahan bobot nilai dari peringkat kinerja pada setiap alternatif pada atribut, sehingga metode ini dapat pengambil keputusan untuk penentuan siswa akselerasi yang sesuai dengan kriteria-kriteria yang telah ditetpkan.

Menurut Lismardiana berjudul Fuzzy MultiAtribute Decision Making (Fuzzy Madm) Dengan Metode Saw Dalam Penentuan Lulusan Mahasiswa Berprestasi penelitian dengan model SAW dan FMADM digunakan untuk perhitungan proses bobot nilai proses perolehan nilai tertinggi kinerja pada setiap alternatif terhadap setiap atribut sehingga pengambilan keputusan lulusan mahasiswa lebih akurat dan efisien.

\subsection{Rumusan Masalah}

Berdasarkan latar belakang, masalah dapat dirumuskan sebagai berikut :

1. Bagaimana cara merancang dan mengimplementasikan sistem pendukung keputusan menggunakan Sublime dengan Xammp?

2. Bagaimana cara mengimplementasikan masalah tersebut dengan menggunakan Metode Fuzzy Multi Decision Making 
(FMADM) dan Simple Additive Weighting (SAW) Algoritma?

\subsection{Tujuan} adalah :

Adapun tujuan dari pengembangan aplikasi ini

1. Mempermudah pengguna untuk mengetahui hasil tes untuk akselerasi .

2. Salah satu cara untuk membantu dalam penentuan hasil tes .

3. Mengimplementasikan penilaian hasil tes akselerasi.

\section{TINJAUAN PUSTAKA}

\subsection{Penelitian Terkait}

Pada penelitian yang dilakukan oleh Anita Dewi Susanti dkk, 2017. Penelitian ini menentukan kriteriakriteria perankingan penerimaan siswa baru menggunakan Sistem Pendukung Keputusan (SPK) untuk penerimaan siswa baru jalur undangan pada SMK Bumi Nusantara Wonosobo untuk membantu penerimaan siswa baru yang berkualitas. Kriteria yang telah ditetakpan ialah kemampuan bahasa inggris, keahlian ekstrakulikuler, tidak buta warna, tamat SMP, nilai SKHU/Ijazah, usia, mengisi formulir, dan sertifikat prestasi. Hasil akhir nilai yang diperoleh maka V1 adalah siswa baru yang berkualitas baik dan memiliki predikat nilai 84 dengan rentan nilai sebagai berikut: $50-70=$ Cukup, $71-82=$ Baik, $83-100=$ Terbaik. . [1]

Selanjutnya pada penelitian Misbahul Munir dkk, 2018. Aplikasi pendukung keputusan merupakan cara mengatasi masalah penentuan beasiswa di universitas tersebut. Program ini menggunakan (SAW) Simple Additive Weigthing. Metode ini menentuksn bobot dari setiap kriteria yang telah ditentukan kemudian dilanjutkan dengan proses normalisasi dan dilanjutkan dengan proses perangkingan untuk menyeleksi alternatif terbaik.. [2]

Pada penelitian Apriansyah putra dkk 2015. Penelitian menggunakan Simple Additive Weighting (SAW). Metode ini untuk menyeleksi alternative terbaik dari sejumlah alternative yang ada. Disini alternative yang dimaksud adalah mahasiswa calon penerima beasiswa berdasarkan kriteria yang ditentukan. Mencari nilai bobot untuk setiap atribut. Kemudian dilakukan proses perengkingan yang menentukan alternative optimal, yaitu mahasiswa terbaik. Bobot yang diberikan pada setiap kriteria mempengaruhi hasil akhir penentuan calon penerima beasiswa. Perubahan nilai bobot pada suatu kriteria mempengaruhi hasil akhir perhitungan. [3]

\subsection{Metode FMADM}

Dalam metode FMADM suatu metode yang digunakan untuk mencari alternatisf optimal dari sejumlah alternatif dengan kriterian tertentu. Algoritma dari FMADM sebagai berikut:

a. Memberi nilai setiap alternatif (Ai) pada setiap karakter (Cj) yang sudah di tentukan, nilai tersebut di peroleh berdasarkan nilai crips $\mathrm{i}=1,2, \ldots \mathrm{m}$ dan $\mathrm{j}=1,2, \ldots \mathrm{n}$.

b. Memberikan nilai bobot (W) berdasarkan nilai crips yang sudah di tentukan

c. Melakukan nilai normalisasi matriks dengan menghitung nilai rating kinerja normalisasi (rij) dari alternatif pada atribut berdasarkan persamaan yang sesuai dengan jenis atribut. Apabila nilai aribut bernilai keuntungan maka nilai crips (xij) dari setiap kolom atribut dibagi dengan nilai crip MAX dari tiap kolom., sedangkan untuk atribut biaya, nilai crips MIN dari setiap kolom atribut dibagi dengan nilai crip setiap kolom.

d. Proses perangkingan dengan cara mengalikan matrik ternomalisasi (R) dengan vector bobot yang sudah ditentukan dan didapatkan nilai terbesar.

e. Menentukan nilai preferensi untuk setiap alternatif (Vi) dengan cara menjumlahkan hasil kali antara matriks ternomalisasi (R) dengan nilai bobot. Nilai $\mathrm{Vi}$ yang lebih besar alternatif $\mathrm{Ai}$ lebih terpilih.

\subsection{Metode SAW}

Konsep dasar metode Simple Additive Weighting (SAW) adalah mencari penjumlahan terbobot dari rating kinerja setiap alternatif pada semua atribut. Metode SAW membutuhkan proses normalisasi matrik keputusan ke suatu skala yang dapat diperbandingkan dengan semua rating alternatif yang ada. Metode ini juga harus pembuat keputusan menentukan bobot bagi setiap atribut. Untuk alternatif di dapat dengan menjumlahkan hasil keseluruhan perangkingan atar rating.

$r_{i j}=\left\{\begin{array}{lc}\frac{x_{i j}}{\max _{i} x_{i j}} & \text { jika j adalah atribut keuntungan benefit } \\ \frac{\min _{i} x_{i j}}{x_{i j}} & \text { jika j adalah atribut biaya (cost) }\end{array}\right\}$

Dimana :

rij = nilai rating kinerja normalisasi

$\mathrm{xij}=$ nilai atribut yang dimiliki setiap kriteria

$\max \mathrm{Xij}=$ nilai maksimum dari setiap kriteria

$\min \mathrm{Xij}=$ nilai minimum dari setiap kriteria

benefit $=$ jika nilai terbesar adalah terbaik

cost $=$ jika nilai terkecil adalah terbaik

Dimana rij adalah rating kinerja ternomalisasi dari alternatif $\mathrm{Ai}$ dan atribut $\mathrm{Cj} ; \mathrm{i}=1,2, \ldots, \mathrm{m}$ dan $\mathrm{j}=$ $1,2, \ldots, n$. Nilai preferensi untuk setiap alternative (Vi) diberikan sebagai :

$$
V i=\sum_{j=1}^{n} W j r i j
$$

Dimana :

$\mathrm{Vi}$ = rangking untuk setiap alternatif

$\mathrm{Wj}=$ nilai bobot dari setiap kriteria

rij = nilai rating kinerja ternormalisasi 


\section{METODE PENELITIAN}

\subsection{Blok Diagram Sistem}

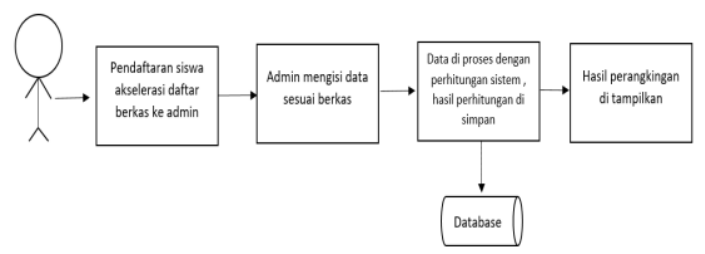

Gambar 1. Blok diagram sistem

Pada gambar 1 dapat diketahui langkah awal admin akan mengumpulkan berkas data calon siswa akselerasi dan admin mengisi data sesuai dengan berkas calon siswa akselerasi . data akan diproses / dihitung menggunakan sistem hasil dari data tersebut tersimpan di database. Hasil dari perengkingan akan di tampilan siswa yang masuk ke dalam kelas akselerasi.

\subsection{Struktur Menu}

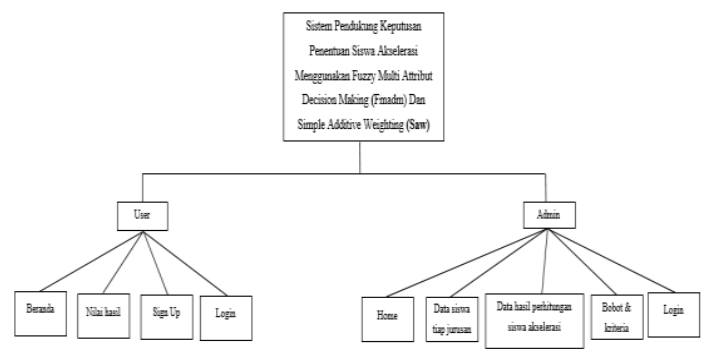

Gambar 2. Struktur menu

Seperti yang terlihat pada Gambar 2. website dapat diakses oleh admin dan siswa. User hanya bisa melihat tentang hasil nilai siswa yang lolos kelas akselerasi. Sedangkan admin bisa input, edit, hapus data nilai siswa yang mengikuti akselerasi dan bisa merubah bobot dan kriterian perhitungan untuk menentukan siswa akselerasi.

\subsection{Flowchart}

\subsubsection{Flowchart Sistem}

Seperti yang dilihat pada Gambar. 3 dilakukan tentang proses alur dari perhitungan metode SAW dan FMADM. Langkah pertama yang harus di lakukan yaitu login untuk admin untuk memasukkan username dan password admin. Setelah melakukan login admin dapat melakukan input, hapus dan edit data nilai siswa. Admin juga bisa melakukan perubahan pada bobot dan kriteria untuk perhitungan penentuan siswa akselerasi. Dihalaman untuk nilai akhir siswa juga terdapat perhitungan penentuan siswa lolos akselerasi. Hasil nilai siswa yang lolos dan tidak lolos.

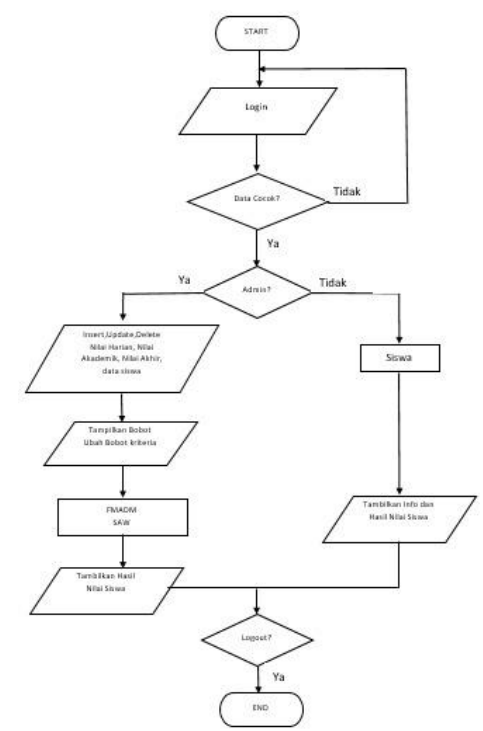

Gambar 3. Flowchart Sistem

\subsubsection{Flowchart Metode}

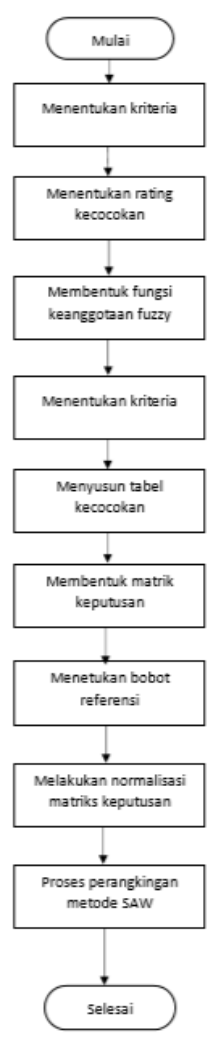

Gambar 5. Flowchart metode

Algoritma 5. 2 menjelaskan tentang proses alur dari perhitungan metode SAW dan FMADM dimulai dengan menentukan kriteria yang akan digunakan dan dijadikan acuan pengambilan keputusan proses penilaian. Memberikan nilai setiap alternatif setiap kriteria yang sudah ditentukan. Memberikan bobot yang di dapatkan berdasarkan nilai crisp. Melakukan normalisasi matriks dengan mengitung nilai rating yang ternomalisasi dari alternatif. Dilakukan proses 
perangkingan dengan cara mengalikan matriks dengan nilai bobot. penentuan nilai untuk setiap alternatif dengan menjumlahkan hasil antara matriks dengan nilai bobot. Nilai yang lebih besar mengindikasikan bahwa alternatif lebih terpilih dari semua alternatif yang ada. Nilai tersebut menjadi hasil akhir dalam penentuan calon siswa akselerasi.

\subsection{Pengujian Metode Fuzzy Multi Artibut Decision Making}

Untuk melakukan konversi data fuzzy ke data crisp, penhujian menggunakan metode

Tsukamoto. Pada konversi ini akan di paparkan 5 sampel peserta seleksi yang telah dilengkapi dengan hasil penilaian. Berikut adalah urian dari masing-masing tahapan metode Tsukamoto yang digunakan pada penelitian ini :

1. Mendefinisikan Karakteristik Model Secara Fungsional dan Operasional.

Tahap mendefinisikan karakteristik model secara fungsional adalah untuk menentukan himpunan fuzzy dan mendefinisikan beberapa fuzzy yang digunakan. Sistem Pendukung Keputusan ini digunakan oleh 3 variabel utama yaitu Nilai Harian, Nilai Akademik dan Nilai Akhir. Dari masing-masing variabel tersebut terdiri dari variabel input yang berbeda. Klasifikasi variabel sistem ini dapat dilihat pada tabel berikut :

Tabel 1 klasifikasi variabel

\begin{tabular}{|c|c|c|c|}
\hline \multicolumn{2}{|c|}{ Variabel } & Range & Nilai \\
\hline \multirow{9}{*}{ Input } & \multirow{3}{*}{$\begin{array}{l}\text { Nilia } \\
\text { Akhir }\end{array}$} & $0<X<65$ & Kecil \\
\hline & & $\begin{array}{c}X>=65 \& \& X \\
<=75\end{array}$ & Sedang \\
\hline & & $75<X<100$ & Tinggi \\
\hline & \multirow{3}{*}{$\begin{array}{l}\text { Nilai } \\
\text { Harian }\end{array}$} & $0<X<70$ & Kecil \\
\hline & & $\begin{array}{c}X>=70 \& \& X \\
<90\end{array}$ & Sedang \\
\hline & & $\begin{array}{c}90<=X<= \\
100\end{array}$ & Tinggi \\
\hline & \multirow{3}{*}{$\begin{array}{c}\text { Nilai } \\
\text { Akademik }\end{array}$} & $0<=X<70$ & Kecil \\
\hline & & $\begin{array}{c}X>=70 \& \& X \\
<90\end{array}$ & Sedang \\
\hline & & $90<X<=100$ & Tinggi \\
\hline
\end{tabular}

Fungsi keanggotaan dari variabel tabel 1 dapat dilihat grafik sebagai berikut :

1. Fungsi keanggotaan Nilai Harian

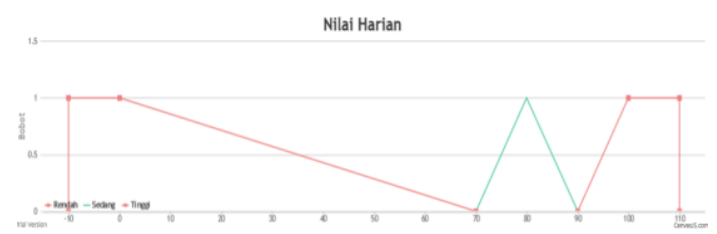

Gambar 6 Grafik Fungki Keanggotan Nilai Harian.

$$
\begin{aligned}
& \mu \text { Kecil }=\left[\begin{array}{cc}
1 & , x \leq 0 \\
\frac{70-x}{70-0} & , x \geq 0 \& \& \quad x<70 \\
0 & , x \geq 70
\end{array}\right. \\
& \mu \text { Sedang }=\left[\begin{array}{cc}
1 & , x \leq 70 ; x \geq 90 \\
\frac{x-70}{80-70} & , x \geq 70 \text { \&\& } x \leq 90 \\
\frac{90-x}{90-80} & , x \geq 80 \& \& x \leq 90
\end{array}\right. \\
& \text { HTing } i=\left[\begin{array}{cc}
0 & , x \leq 90 \\
\frac{x-90}{100-90} & , x>90 \& \& \quad x<100 \\
1 & , x \geq 100
\end{array}\right.
\end{aligned}
$$

2. Fungsi keanggotaan Nilai Akademik

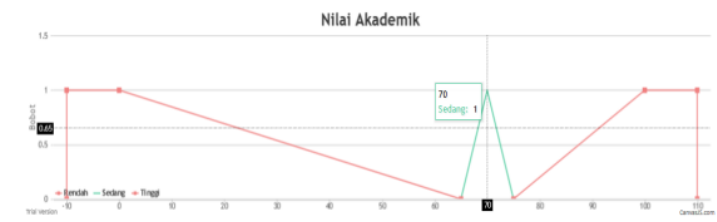

Gambar 7 Grafik Fungki Keanggotan Nilai Akademik

$\mu$ Kecil $=\left[\begin{array}{cc}1 & , x \leq 0 \\ \frac{70-x}{70-0} & , x \geq 0 \& \& \quad x<70 \\ 0 & , x \geq 70\end{array}\right.$

$$
\begin{aligned}
& \mu \text { Sedang }=\left[\begin{array}{cc}
1 & , x \leq 70 ; x \geq 90 \\
\frac{x-70}{80-70} & , x \geq 70 \& \& \quad x \leq 90 \\
\frac{90-x}{90-80} & , x \geq 80 \& \& x \leq 90
\end{array}\right. \\
& \mu \text { Tinggi }=\left[\begin{array}{cc}
0 & , x \leq 90 \\
\frac{x-90}{100-90} & , x>90 \& \& \quad x<100 \\
1 & , x \geq 100
\end{array}\right.
\end{aligned}
$$

3. Fungsi keanggotaan Nilai Akhir

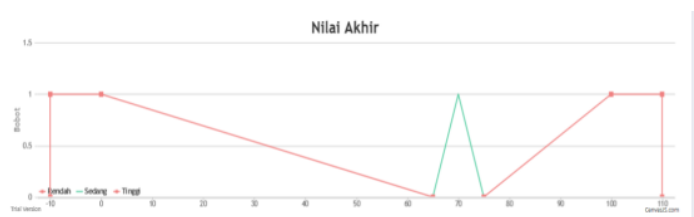

Gambar 7 Grafik Fungki Keanggotan Nilai Akhir

$$
\begin{aligned}
& {\left[\begin{array}{cc}
1 & , x \leq 0 \\
\frac{65-x}{65-0} & , x \geq 0 \& \& \quad x<65 \\
0 & , x \geq 65
\end{array}\right.} \\
& \mu \text { Sedang }=\left[\begin{array}{cc}
1 & , x \leq 65 ; x \geq 75 \\
\frac{x-65}{70-65} & , x \geq 65 \& \& \quad x \leq 75 \\
\frac{75-x}{75-70} & , x \geq 70 \& \& x \leq 75
\end{array}\right. \\
& \mu \text { Tinggi }=\left[\begin{array}{cc}
0 & , x \leq 75 \\
\frac{x-75}{100-75} & , x>75 \& \& \quad x<100 \\
1 & , x \geq 100
\end{array}\right.
\end{aligned}
$$


Untuk melakukan konversi data fuzzy ke data crisp, penhujian menggunakan metode Tsukamoto. Pada perhitungan ini di paparkan sampel perhitungan yang akan di seleksi dengan hasil penilaian. Data yang digunakan sebagai simulasi perhitungan adalah data nilai input sebagai berikut:

\begin{tabular}{|l|c|c|c|c|}
\hline \multirow{2}{*}{ No } & \multirow{2}{*}{ Nama } & \multicolumn{3}{|c|}{ Kriteria } \\
\cline { 3 - 5 } & & $\begin{array}{c}\text { Nilai } \\
\text { Harian }\end{array}$ & $\begin{array}{c}\text { Nilai } \\
\text { Akhir }\end{array}$ & $\begin{array}{c}\text { Nilai } \\
\text { Akademik }\end{array}$ \\
\hline \multirow{2}{*}{1.} & Agusantoso & 78.4 & 84.13 & 82.7 \\
\hline
\end{tabular}

Menghitung Nilai Keaggotaan dari masingmasing variabel input yang telah di tetapkan.

i. Variabel Nilai Harian

Berdasarkan fungsi keanggotaan Nilai Akhir maka nilai input pada variabel Nilai Akhir 78 masuk ke dalam kategori "sedang". Sehingga nilai keanggotaannya kategori sedamg :

$\mu$ Sedang $=\frac{78.4-70}{80-70}=0.84$

ii. Variabel Nilai Akademik

Berdasarkan fungsi keanggotaan Nilai Akademik maka nilai input pada variabel Nilai Akademik 84 masuk ke dalam kategori "tinggi”. Sehingga nilai keanggotaannya kategori tinggi :

$\mu$ Ting $g i=\frac{84.13-75}{100-75}=0.3652$

iii. Variabel Nilai Akhir

Berdasarkan fungsi keanggotaan Nilai Harian maka nilai input pada variabel Nilai Harian 82 masuk ke dalam kategori "Tinggi". Sehingga nilai keanggotaannya kategori tinggi :

$\mu$ Tinggi $=\frac{82.7-75}{100-75}=0.3652$

Setelah mengetahui nilai keanggotaan masingmasing variabel, maka selanjutnya adalah melakukan Inferensi sesuai dengan aturan yang telah ditentukan. Dilanjutkan dengan menghitung defuzzyfikasi untuk mendapatkan nilai output variabel. Aturan yang telah ditentukan pada variabel ini di dapatkan 27 aturan.

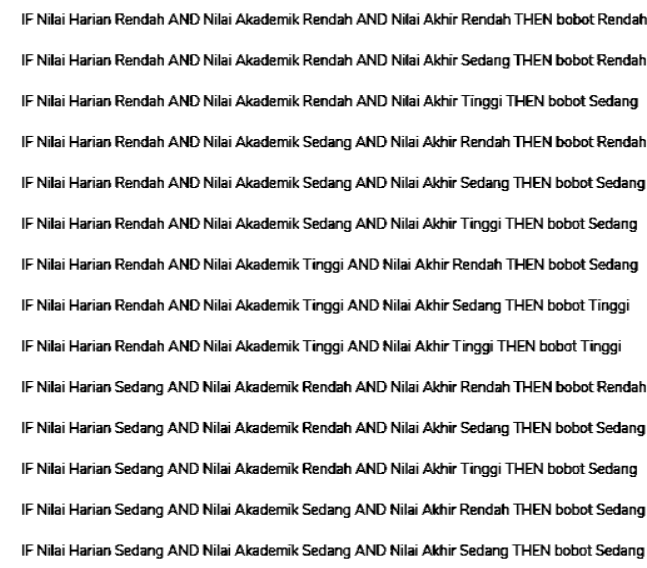

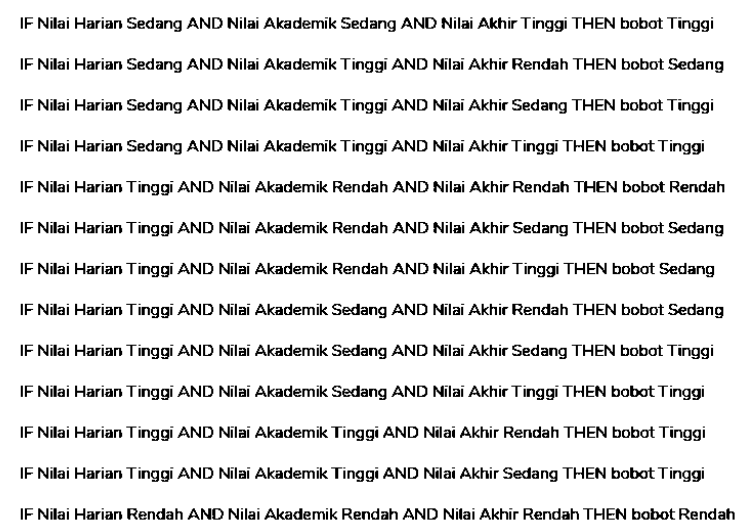

Dengan demikian nilai keagotaan dari hasil evaluasi variaebel berdasarkan aturan yang digunakan sebagai berikut:

Rule 1

$$
\begin{aligned}
& \alpha_{\text {pred }_{1}}=\max \{0,0,0\}=0 \\
& \begin{aligned}
z_{1} & =0.3-(0 *(0.3-0) \\
& =0.3-0=0.3
\end{aligned}
\end{aligned}
$$

Rule 2

$$
\begin{aligned}
& \alpha_{\text {pred }_{2}}=\max \{0,0,0\}=0 \\
& \begin{aligned}
z_{2} & =0.3-(0 *(0.3-0) \\
& =0.3-0=0.3
\end{aligned}
\end{aligned}
$$

Rule 3

$$
\alpha_{\text {pred }_{a}}=\max \{0,0,0.827\}=0.827
$$$$
z_{3}=0.8
$$

Rule 4

$$
\begin{aligned}
& \alpha_{\text {pred }_{4}}=\max \{0,0,0\}=0 \\
& \Xi_{4}=0.3-(0 *(0.3-0) \\
& \quad=0.3-0=0.3
\end{aligned}
$$

Rule 5

$\alpha_{\text {pred }_{5}}=\max \{0,0,0\}=0$

$\mathbb{Z}_{5}=0.8$

Rule 6

$\alpha_{\text {pred }_{6}}=\max \{0,0,0.827\}=0.827$

$z_{6}=0.8$

Rule 7

$$
\begin{aligned}
& \alpha_{\text {pred }_{7}}=\max \{0,0.3652,0\}=0.3652 \\
& \begin{aligned}
\mathrm{z}_{7} & =(0.3652 *(0.5-0.2))+0.2 \\
& =0.10956-0.2=0.30956
\end{aligned} \\
& \text { Rule } 8 \\
& \begin{array}{l}
\alpha_{\text {pred }}=\max \{0,0.3652,0\}=0.3652 \\
\mathrm{z}_{8}=(0.3652 *(1-0.7))+0.7 \\
\quad=0.10956-0.7=0.80956
\end{array}
\end{aligned}
$$

Rule 9

$$
\begin{aligned}
& \alpha_{\text {pred }_{9}}=\max \{0,0.3652,0.827\}=0.827 \\
& \begin{aligned}
z_{9} & =(0.827 *(1-0.7))+0.7 \\
& =0.2481-0.7=0.9481
\end{aligned} \\
& \text { Rule } 10 \\
& \begin{aligned}
\alpha_{\text {pred }_{10}}=\max \{0.84,0,0\}=0.84 \\
z_{10}=0.3-(0.84 *(0.3-0) \\
\quad=0.3-0.252=0.048
\end{aligned}
\end{aligned}
$$


Rule 11

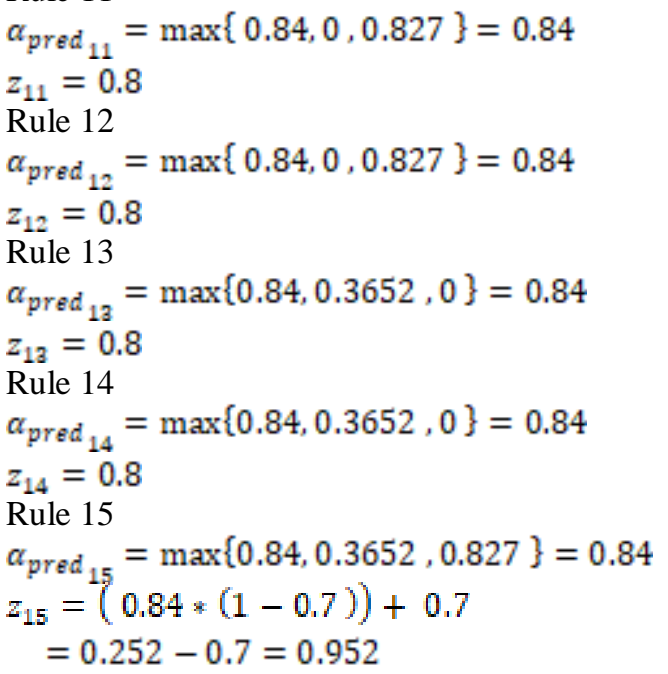

Rule 16

$\alpha_{\text {pred }_{16}}=\max \{0.84,0,0\}=0.84$

$z_{16}=0.8$

Rule 17

$\alpha_{\text {pred }}=\max \{0.84,0,0\}=0.84$

$z_{17}=(0.84 *(1-0.7))+0.7$

$$
=0.252-0.7=0.952
$$

Rule 18

$\alpha_{\text {pred }}=\max \{0.84,0,0.827\}=0.84$

$z_{19}=(0.84 *(1-0.7))+0.7$

$=0.252-0.7=0.952$

Rule 19

$$
\begin{aligned}
& \alpha_{\text {pred }_{19}}=\max \{0,0,0\}=0 \\
& \begin{aligned}
\mathrm{z}_{19} & =0.3-(0 *(0.3-0) \\
& =0.3-0=0.3
\end{aligned}
\end{aligned}
$$

Rule 20

$\alpha_{\text {pred }_{20}}=\max \{0,0,0\}=0$

$z_{20}=0.8$

Rule 21

$\alpha_{\text {pred }_{21}}=\max \{0,0,0\}=0$

$\mathbb{B}_{21}=0.8$

Rule 22

$\alpha_{\text {pred }_{22}}=\max \{0,0,0\}=0$

$\mathrm{z}_{22}=0.8$

Rule 21

$\alpha_{\text {pred }_{21}}=\max \{0,0,0.821\}=0.821$

$z_{21}=0.8$

Rule 22

$\alpha_{\text {pred }_{22}}=\max \{0,0,0\}=0$

$z_{22}=0.8$

Rule 23

$\alpha_{\text {pred }_{23}}=\max \{0,0,0\}=0$

$z_{21}=0.7$

Rule 24

$$
\begin{aligned}
& \alpha_{\text {pred }_{24}}=\max \{0,0,0.827\}=0.827 \\
& \Xi_{24}=(0.827 *(1-0.7))+0.7 \\
& \quad=0.2481-0.7=0.9481
\end{aligned}
$$

Rule 25

$$
\begin{aligned}
& \alpha_{\text {pred }_{25}}=\max \{0,0.3652,0\}=0.3652 \\
& z_{24}=(0.362 *(1-0.7))+0.7 \\
& \quad=0.10956-0.7=0.80956
\end{aligned}
$$

Rule 26

$$
\begin{aligned}
& \alpha_{\text {pred }}=\max \{0,0.3652,0\}=0.3652 \\
& \mathbb{z}_{24}=(0.3652 *(1-0.7))+0.7 \\
& \quad=0.10956-0.7=0.80956
\end{aligned}
$$

Rule 27

$$
\begin{aligned}
& \sigma_{\text {pred }_{24}}=\max \{0,0.3652,0.827\}=0.827 \\
& \begin{aligned}
\Xi_{24} & =(0.827 *(1-0.7))+0.7 \\
& =0.2481-0.7=0.9481
\end{aligned}
\end{aligned}
$$

Hasil dari perhhitungan aturan diatas dilanjutkan dengan defuzzyfikasi sebgai berikut :

$\mathrm{Z}=((0 * 0.3)+(0 * 0.3)+(0.827 * 0.8)+(0 * 0.3)+(0$

$* 0.8)+(0.827 * 0.8)$

$+(0.3652 * 0.30956)+(0.3652 * 0.80956)+(0.827 *$ $0.9481)+(0.84 * 0.048)$

$+(0.84 * 0.8)+(0.84 * 0.8)+(0.84 * 0.8)+(0.84 *$ $0.8)+(0.84 * 0.952)$

$+(0.84 * 0.8)+(0.84 * 0.952)+(0.84 * 0.952)+(0 *$ $0.3)+(0 * 0.8)+(0.827 * 0.8)$

$+(0 * 0.8)+(0 * 0.7)+(0.827 * 0.9481)+(0.3652 *$ $0.80956)$

$+(0.3652 * 0.80956)+(0.827 * 0.9481))$

/ $0+0+0.827+0+0+0.827+0.3652+0.3652+$ $0.827+0.84+0.84+0.84+0.84+0.84+0.84+0.84+$ $0.84+0.84+0+0+0.827+0+0+0.827+0.3652+$ $0.3652+0.827$

$\mathrm{Z}=11.136401348 / 13.9828$

$\mathrm{Z}=0.79643571730984$

\subsection{Pengujian Simple Additive Weigthing.}

Hasil data uji dari perhitungan fuzzy diatas adalah 0.79643571730984. Data uji akan di kalikan dengan bobot $\mathbb{3} 30,30,40 \mathbb{~}$. Hasil yang sudah di kalikan adalah :

Total $=(0.79643571730984 * 30)+(0.79643571730984$ $* 30)+(0.79643571730984 * 40)=79.643571730984$

\section{HASIL DAN PEMBAHASAN}

4.1 Hasil Akhir perhitungan Excel

Dengan menggunakan metode SAW dan

FMADM yang dihitung manual pada excel didapatkan hasil yang dapat dilihat pada tabel 6 .

Tabel 6 perhitungan di excel

\begin{tabular}{|c|c|c|c|c|}
\hline \multicolumn{3}{|c|}{ Normalisasi } & \multirow{2}{*}{ Total } & \multirow{2}{*}{ Hasil } \\
\hline C1 & C2 & C3 & & $\begin{array}{c}\text { TIDAK } \\
\text { LOLOS }\end{array}$ \\
\hline 0.496 & 1 & 0.393 & 0.65 & LOLOS \\
\hline 0.820 & 0.986 & 0.639 & 0.83 & \\
\hline
\end{tabular}

\subsection{Tampilan hasil perhitungan pada sistem}

Pada gambar 6 adalah tampilan hasil perhitungan menggunakan metode SAW dan FMADM. Dimana user dapat melihat hasil penentuan siswa. 


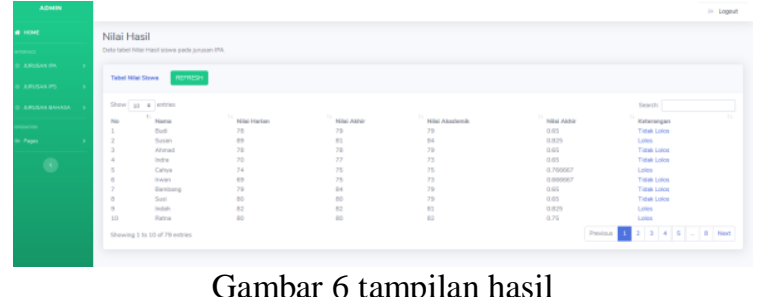

Gambar 6 tampilan hasil

4.3 Hasil pengujian fungsional Pengujian pnentuan siswa akselerasi. Seperti pada tabel 7

Tabel 7 pengujian fungsional

\begin{tabular}{|l|c|c|}
\hline \multicolumn{1}{|c|}{ Fungsi } & $\begin{array}{c}\text { Google } \\
\text { Chrome }\end{array}$ & Firefox \\
\hline Login dan Sesi & $\checkmark$ & $\checkmark$ \\
\hline Menu utama admin & $\checkmark$ & $\checkmark$ \\
\hline $\begin{array}{l}\text { Daftar nilai siswa setiap } \\
\text { jurussaan }\end{array}$ & $\checkmark$ & $\checkmark$ \\
\hline Tambah nilai siswa & $\checkmark$ & $\checkmark$ \\
\hline Rubah nilai bobot kriteria & $\checkmark$ & $\checkmark$ \\
\hline Daftar hasil nilai siswa & $\checkmark$ & $\checkmark$ \\
\hline $\begin{array}{l}\text { Perhitungan metode } \\
\text { SAW \& FMADM }\end{array}$ & $\checkmark$ & $\checkmark$ \\
\hline Fungsi Logout & $\checkmark$ & $\checkmark$ \\
\hline
\end{tabular}

\section{KESIMPULAN DAN SARAN}

\subsection{Kesimpulan}

Adapun kesimpulan yang dapat penulis uraikan setelah melakukan perancangan dan pembuatan sistem pendukung keputusan menggunakan metode SAW dan FMADM adalah sebagai berikut :

1. Dari hasil pengujian fungsional sistem diperoleh bahwa fungsi yang terdapat dalam sistem $100 \%$ dapat dijalankan dengan menggunakan web browser yang berbeda yaitu Mozila Firefox dan Google Chrome.

2. Dari hasil perhitungan sistem dan perhitungan manual metode Fuzzy Multi Atribut Decision Making (FMADM) dan Simple Additive Weighting (SAW).untuk penentuan siswa akselerasi maka didapatkan presentase kesalahan (error) sebesar 7,88\%.

\subsection{Saran}

Berdasarkan kesimpulan yang telah diuraikan diatas, maka diberikan saran sebagai berikut :

1. Dikembangkan dengan menambahkan fitur grafik untuk mengetahui tingakat prestasi yang dimiliki oleh siswa.

2. Dikembangkan dengan menambahkan fitur hasil prestasi setiap siswa.

\section{DAFTAR PUSTAKA}

[1] Dewi Susanti, A. Muhamad, M. Sri Hartati, Sistem Pendukung Keputusan Perankingan Calon Siswa Baru Jalur Undangan Menggunakan Simple Additive Weighting (Studi Kasus : Smk Bumi Nusantara Wonosobo), ISSN 2302-3805, Februari 2017.

[2] Misbahul. M, Fitri Marisa, Dwi.P, Sistem Penunjang Keputusan Dalam Pengklasifikasian Mahasiswa Penerima Beasiswa Dengan Metode Simple Additive Weighting Di Universitas Widyagama Malang, Jurnal Spirit, ISSN 2085-3092 No.2 Vol 10, Nopember 2018.

[3] Rohmat Taufiq, Ikhsan.S.M, Perancangan Sistem Pendukung Keputusan Kejurusan Menggunakan Metode Simple Additive Weighting (Saw) Di Sma Negri 15 Tangerang, Jurnal TI Atma Luhur, No.1 Vol.4, September 2017.

[4] Apriansyah Putra, Dinna .Y.H, Penentuan Penerima Beasiswa Dengan Menggunakan Fuzzy Multiple Atribute Decission Making, Jurnal Sistem Informasi (JSI), ISSN 2355-4614, No.1 Vol.3, April 2011.

[5] Supartha, I Kadek D.G., Dewi, I Gusti Ayu P.E.P., Sistem Pendukung Keputusan Penentuan Jurusan Pada SMK Kertha Wisata Denpasar Menggunakan Fuzzy SAW, Jurnal Nasional Pendidikan Teknik Informatika (JANAPATI), ISSN 2089 - 8673 No. 2 Vol. 3, Juli 2014.Menggunakan Metode K-Means. Ilkom Jurnal Ilmiah, 8(2), 89-94. 